\title{
Chitinase Chit62J4 Essential for Chitin Processing by Human Microbiome Bacterium Clostridium paraputrificum J4
}

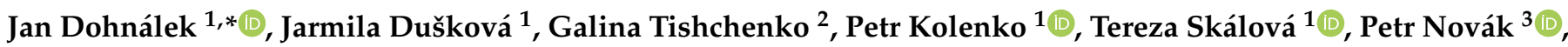 \\ Karla Fejfarová ${ }^{1}$ and Jiří Šimůnek ${ }^{4}$
}

1 Laboratory of Structure and Function of Biomolecules, Institute of Biotechnology of the Czech Academy of Sciences, v. v. i., Biocev, Průmyslová 595, 25250 Vestec, Czech Republic; duskovaj@ibt.cas.cz (J.D.); petr.kolenko@ibt.cas.cz (P.K.); tereza.skalova@ibt.cas.cz (T.S.); karlafej@gmail.com (K.F.)

2 Department of Structural Analysis of Biomacromolecules, Institute of Macromolecular Chemistry of the Czech Academy of Sciences, v. v. i., Heyrovsky Sq. 2, 16206 Prague, Czech Republic; gtiscenko@gmail.com

3 Laboratory of Structural Biology and Cell Signaling, Institute of Microbiology of the Czech Academy of Sciences, v. v. i., Biocev, Průmyslová 595, 25250 Vestec, Czech Republic; pnovak@biomed.cas.cz

4 Laboratory of Anaerobic Microbiology, Institute of Animal Physiology and Genetics of the Czech Academy of Sciences, v. v. i., Vídeňská 1083, 14200 Prague, Czech Republic; juraseksimunek@seznam.cz

* Correspondence: dohnalek@ibt.cas.cz; Tel.: +420-325-873-758; Fax: +420-325-873-710

check for updates

Citation: Dohnálek, J.; Dušková, J.; Tishchenko, G.; Kolenko, P.; Skálová, T.; Novák, P.; Fejfarová, K.; Šimůnek, J. Chitinase Chit62J4 Essential for Chitin Processing by Human Microbiome Bacterium Clostridium paraputrificum J4. Molecules 2021, 26 , 5978. https://doi.org/10.3390/ molecules26195978

Academic Editor: Stefan Janecek

Received: 2 July 2021

Accepted: 27 September 2021

Published: 2 October 2021

Publisher's Note: MDPI stays neutral with regard to jurisdictional claims in published maps and institutional affiliations.

Copyright: (c) 2021 by the authors. Licensee MDPI, Basel, Switzerland. This article is an open access article distributed under the terms and conditions of the Creative Commons Attribution (CC BY) license (https:// creativecommons.org/licenses/by/ $4.0 /)$.

\begin{abstract}
Commensal bacterium Clostridium paraputrificum J4 produces several extracellular chitinolytic enzymes including a $62 \mathrm{kDa}$ chitinase Chit62J4 active toward 4-nitrophenyl $N, N^{\prime}$-diacetyl- $\beta$ D-chitobioside (pNGG). We characterized the crude enzyme from bacterial culture fluid, recombinant enzyme rChit62J4, and its catalytic domain rChit62J4cat. This major chitinase, securing nutrition of the bacterium in the human intestinal tract when supplied with chitin, has a $\mathrm{pH}$ optimum of 5.5 and processes pNGG with $K_{\mathrm{m}}=0.24 \mathrm{mM}$ and $k_{\text {cat }}=30.0 \mathrm{~s}^{-1}$. Sequence comparison of the amino acid sequence of Chit62J4, determined during bacterial genome sequencing, characterizes the enzyme as a family 18 glycosyl hydrolase with a four-domain structure. The catalytic domain has the typical TIM barrel structure and the accessory domains-2x Fn3/Big3 and a carbohydrate binding module - that likely supports enzyme activity on chitin fibers. The catalytic domain is highly homologous to a single-domain chitinase of Bacillus cereus NCTU2. However, the catalytic profiles significantly differ between the two enzymes despite almost identical catalytic sites. The shift of pI and $\mathrm{pH}$ optimum of the commensal enzyme toward acidic values compared to the soil bacterium is the likely environmental adaptation that provides C. paraputrificum $\mathrm{J} 4$ a competitive advantage over other commensal bacteria.
\end{abstract}

Keywords: human commensal bacterium; chitinase; exochitinase; glycosyl hydrolase family 18; adaptation to the environment

\section{Introduction}

Bacteria in the large intestine are one of the most diverse microbial communities in nature [1]. These microbial communities rely on digestible proteins, fats, and poly- and oligosaccharides as an energy source as well as on non-digestible polysaccharides reaching the colon. The ability to utilize non-digestible polysaccharides plays an important role in maintaining the equilibrium of individual bacterial species in the mammalian microbiome. This has an impact through microbial ecology on human health [2]. Most non-digestible polysaccharides originate from plants and other natural foods, but a significant proportion come from insects or artificial chitin-based or chitin-derived nutrition, among other sources [3]. The occurrence of commensal bacterial species capable of chitin degradation illustrates the adaptation of the human microbiome to the environment and nutrition development or variation [4]. Convergence of enzymatic functions of carbohydrate-active genes under environmental pressure in human gut microbes was first illustrated in glycoside 
hydrolases and glycosyltransferases, with horizontal gene transfer and parallel gene loss being the expected primary mechanisms [5].

Gram-positive bacteria with low GC content form the most abundant bacterial group of the intestinal microbiome [1]. The distribution of individual microbiome species along the human colon is not uniform but is influenced by several factors. According to [6], the change of $\mathrm{pH}$ along the human gut may be responsible for a major drift within the human fecal bacterial community. In particular, the growth of a major group of Gram-negative bacteria is inhibited at mildly acidic $\mathrm{pH}$, thus creating space for a lower $\mathrm{pH}$-tolerant microorganism. Clostridial clusters of bacteria are significantly more abundant at $\mathrm{pH} 5.5$ compared to $\mathrm{pH}$ 6.5. However, when considering chitin digestion, colonization of insoluble polysaccharide fibers in the intestine may have a more complex pattern with respect to $\mathrm{pH}$ and its local variation, although detailed knowledge in this area is missing. However, a bacterium able to tolerate lower $\mathrm{pH}$, typical for the proximal parts of the human colon, while digesting chitin or its derivatives, would have an advantage in competition with other intestinal microflora under specific conditions.

Particular adaptations of human gut microbial enzymes under highly competitive microbiome conditions at the level of enzyme structure and function have been given little attention. However, one example is a study of $\alpha$-glucosidase from Ruminococcus obeum, capable of producing glucose from both isomaltose and maltose [7].

Chitinases (E.C. 3.2.1.14) are enzymes cleaving the $\beta-1,4$ bond of the natural polysaccharide chitin, composed of $N$-acetyl-D-glucosamine units (GlcNAc)n. Bacterial chitinases have been studied and utilized for biotechnological purposes [8,9]. Chitinases belong to glycosyl hydrolase (GH) classes, GH18, 19, 23 and 48 [10,11]. The GH18 family contains archaeal, bacterial, eukaryotic, and viral chitinases, family 19 only bacterial and eukaryotic ones, and family 48 mainly eukaryotic ones. Chitinases of the GH18 family perform hydrolysis while retaining the $\mathrm{C} 1$ configuration, the enzymes of GH19 and 48 utilize an inverting mechanism, while for one $\mathrm{GH} 23$ chitinase, a tunnel-like catalytic cavity relying on two acidic residues has been described [12]. GH18 chitinases utilize a conserved glutamic acid residue in the catalytic center and produce single GlcNAc units, disaccharides or higher oligosaccharides.

To date, the structure, function, and biotechnological application of primarily bacterial and fungal GH18 chitinases have been the focus of further studies [13]. However, research on the role of chitinases in human health has grown after the publication of the human genome. Humans express an acidic mammalian chitinase connected with asthma in addition to other chitinases or chitinase-like proteins of the family GH18 [14,15]. Recent studies have focused on proteins of human commensal organisms, such as intestinal bacteria $[4,16]$, which can serve either as markers of health state, potential active substances against candidoses or triggers for colon-specific drug delivery [17].

Clostridium paraputrificum $\mathrm{J} 4$ is one of the bacterial species in the gastrointestinal tract of a healthy human. The strain C. paraputrificum J4 was discovered by Simunek et al. [4] as a strictly anaerobic bacterium, which can survive on chitin as the sole source of carbon. We have identified at least five different chitinases in the extracellular extracts of this bacterium [16] and have characterized the main components with endo-, exochitinase and $\mathrm{N}$-acetylglucosaminidase activity. Complete genomes of thirty-two other clostridia, excluding C. paraputrificum J4, have been annotated (NCBI, http:/ / www.ncbi.nlm.nih.gov/ genome/, accessed on 25 April 2021), twenty of which do not contain any chitinase and only one that has at least two predicted chitinases. Within clostridia, only C. paraputrificum $\mathrm{J} 4$ harbors genes for such a high number of chitinolytic enzymes.

C. paraputrificum J4 secretes enzymes in support of its nutrition in the human intestine, where chitin or chitooligosaccharides cannot be normally processed by human enzymes, which raises questions about the source of chitin in humans. Chitin, chitosan, and derived substances have been used in the food industry as antimicrobial agents, for beverage clarification, and in pharmaceutical and therapeutic applications, etc. $[18,19]$. These applications, apart from food contamination by fungi, explain the occurrence of a commensal 
bacterium well equipped for chitin degradation. Fungal infections can become a major issue in human health and more effective means of treatment are sought [20]. Chitinases, capable of degradation of chitin-containing fungal cell walls and originating from human symbionts, may be used in applications against candidoses or in targeted drug release [21].

The research efforts directed at the understanding of the interactions of the SARS$\mathrm{CoV}-2$ virus within humans, indicated, among other effects, infection-related changes in microbiome composition [22] as an important direction for diagnostic development and understanding the fitness of the human immune system. Better understanding of the molecular details behind microbiome development and interdependencies between a healthy human and commensal species should provide a solid base for further developments in diagnostics and treatment of pathogen-borne diseases.

In this work, we characterized an isolated form and two recombinant forms of the most abundant chitinase of the human commensal bacterium Clostridium paraputrificum J4. We bring functional analysis and insights into the domain structure of the major chitinase of this bacterium and evidence of gene/enzyme adjustment to the typical conditions of the human colon environment.

\section{Materials and Methods}

\subsection{Bacterium Cultivation and Culture Fluid Treatment}

A strictly anaerobic mesophilic chitinolytic bacterial strain C. paraputrificum J4 was isolated from human feces [23]. The final identification was performed by sequencing of a 16S rDNA fragment (GenBank accession no: KX766027.1, UniProtKB accession no.: A0A1C9J7J5). The bacterium was grown on modified medium M10 [24], containing colloidal chitin $(4 \mathrm{~g} / \mathrm{L})$ as the substrate to induce the synthesis of chitinolytic enzymes. At the exponential phase of growth, the cells were harvested by centrifugation at $35000 \times g$ for 15 min at $4{ }^{\circ} \mathrm{C}$.

\subsection{Purification and Identification of Crude Enzyme crChit62J4}

Sample preparation for preparative chromatographic separation of the chitinolytic enzymes from the supernatant of the culture fluid is described in [25]. Briefly, the bacteriafree supernatant was filtered through 100-kDa and 30-kDa PES (polyethersulfone) Millipore membranes under an applied pressure of $50 \mathrm{kPa}$ to partially separate solutes with molecular weight (MW) higher than $100 \mathrm{kDa}$ and lower than $30 \mathrm{kDa}$, respectively. The main fraction of chitinolytic enzymes was retained with a PES membrane with $30 \mathrm{kDa}$ cut-off. It was approximately $25 \times$ concentrated.

The retentate was dialyzed ( $3 \mathrm{kDa}$ cut-off, Spectrum Medical Diagnostics Inc., Mississauga, ON, Canada) against the buffer A $(0.05 \mathrm{M}$ Tris- $\mathrm{HCl}, \mathrm{pH} 7.5)$ and loaded onto a pseudo-affinity support (strong anion-exchange resin DOWEX- $1 \times 2$ with fixed counterions of EDTA). It showed strong affinity to colored admixtures accompanying the target enzymes. Several of the chitinolytic enzymes left the pseudo-affinity column at sorption and during washing with loading buffer A. Adsorbed chitinolytic enzymes were desorbed under a linear gradient of $\mathrm{NaCl}(0-0.5 \mathrm{M})$ in buffer $\mathrm{A}$. The chitinolytic enzymes were eluted in two strongly overlapping peaks in the $0.02-0.1 \mathrm{M} \mathrm{NaCl}$ range. The combined fractions of the second and the third peak were dialyzed ( $3 \mathrm{kDa}$ cut-off) against buffer $\mathrm{A}$, concentrated by vacuum evaporation and purified on a DEAE Sepharose Fast Flow anion exchange column under the same sorption and elution conditions.

Enzymes were further separated by size exclusion chromatography using HiLoad 16/60, Superdex 75 prep grade equilibrated with $50 \mathrm{mM} \mathrm{HK} \mathrm{PO}_{4} / \mathrm{H}_{2} \mathrm{KPO}_{4}, 150 \mathrm{mM}$ $\mathrm{NaCl}$, pH 7.0 and then polished by chromatofocusing using MonoP 5/200 GL equilibrated in 0.25 M BisTris, pH 7.5 and eluted by Polybuffer74, pH 4.0 (all columns by GE Healthcare Life Sciences, Marlborough, MA, USA). The enzyme was concentrated in $0.1 \mathrm{M}$ $\mathrm{HK}_{2} \mathrm{PO}_{4} / \mathrm{H}_{2} \mathrm{KPO}_{4}, \mathrm{pH} 7.0$ to $4.5 \mathrm{mg} / \mathrm{mL}$. Sample purity was verified using sodium dodecyl sulfate (SDS) gel electrophoresis and activity using zymograms [4]. Molecular mass analysis was performed on a subset of enzymes using matrix-assisted laser desorption/ionization- 
time of flight mass spectrometry (BIFLEX III spectrometer, Bruker). Preselected samples according to mass estimates and detected activity were submitted for peptide fragment mass spectrometry analysis.

\subsection{Recombinant Expression}

DNA coding for both rChit62J4 (resulting product sequence, tag and cleavage site residues are underlined: MGSSHHHHHHSSGENLYFQGGTHMLEAQSL ... WQKQ, 598 amino acid residues, theoretical MW $65.222 \mathrm{kDa}$ ) and rChit62J4cat (MGSSHHHHHHSSGEN LYFQGGTHMLEAQSL . . . LTPV, 357 a.a., $39.395 \mathrm{kDa}$ ) was amplified by PCR using primers incorporating Xho I and BamHI restriction sites (Supplementary Table S1) and subcloned into a pET-15bTEV expression vector. The DNA sequences were verified by sequencing using vector-specific primers. Proteins were heterologously expressed in E. coli BL-21 (DE3) in LB medium induced by the addition of $0.5 \mathrm{mM}$ IPTG (isopropyl $\beta$-D-1-thiogalactopyranoside) at $37^{\circ} \mathrm{C}$. Cells were disrupted using sonication after $4 \mathrm{~h}$ of target protein expression. The proteins were purified using a Ni-NTA Superflow ${ }^{\mathrm{TM}}$ gravity column (QIAGEN, Hilden, Germany), washed with $50 \mathrm{mM}$ imidazole and eluted with $200 \mathrm{mM}$ imidazole. The last step in protein purification was size exclusion chromatography using Superdex 200 (buffer $0.5 \mathrm{M} \mathrm{H}_{2} \mathrm{KPO}_{4} / \mathrm{HK}_{2} \mathrm{PO}_{4}, \mathrm{pH} 7$ ), and isofocusing using a MonoP column equilibrated in $0.025 \mathrm{mM}$ BisTris, $\mathrm{pH} 7.0 \mathrm{pH}$ and eluted with a $\mathrm{pH}$ gradient by Polybuffer75 $\mathrm{pH}$ 4.0. The quality of the resulting protein samples was monitored using SDS-PAGE (Supplementary Figure S1).

\subsection{DNA Isolation and Genomic Sequencing}

DNA of C. paraputrificum J4 was isolated from 3-days-old culture using the QIAamp DNA Stool Mini kit (QIAGEN, Hilden, Germany). Shotgun genomic sequencing using Illumina Hiseq2000, together with genome assembly and initial bioinformatics analysis was performed by CD Genomics (Shirley, NY, USA). Protein coding sequences contained the sequence of Chit62J4 together with other chitin-degrading enzymes.

\subsection{Proteolytic Digestion and Mass Spectrometry Analysis}

Crude enzyme was analyzed in protein bands cut from SDS denaturing gel and zymogram and in purified form using trypsin proteolysis and matrix-assisted laser desorption/ ionization-Fourier transform mass spectrometry analysis. Protein bands were cut from gel, cut into small pieces, and decolorized in sonic bath at $60{ }^{\circ} \mathrm{C}$ several times with $0.1 \mathrm{M}$ 4ethylmorpholine acetate ( $\mathrm{pH} 8.1$ ) in $50 \%$ acetonitrile (ACN). After complete destaining, proteins were reduced by $50 \mathrm{mM}$ tris-(2-Carboxyethyl)phosphine in $0.1 \mathrm{M}$ 4-ethylmorpholine acetate ( $\mathrm{pH} \mathrm{8.1)} \mathrm{for} 5 \mathrm{~min}$ at $80^{\circ} \mathrm{C}$ and alkylated using $50 \mathrm{mM}$ iodoacetamide in $0.1 \mathrm{M}$ 4-ethylmorpholine acetate ( $\mathrm{pH} 8.1$ ) for $30 \mathrm{~min}$ in the dark at room temperature. Then, the gel was washed with water, shrunk by dehydration with ACN, and reswollen in water. The rehydration and dehydration of the gel was repeated twice. Next, the gel was reswollen in $0.05 \mathrm{M}$ 4-ethylmorpholine acetate (pH 8.1) in 50\% ACN and then the gel was partly dried using a SpeedVac concentrator (Savant, Holbrook, NY, USA). Finally, the gel was reconstituted with cleavage buffer containing 0.01\% 2-mercaptoethanol, $0.05 \mathrm{M}$ 4-ethylmorpholine acetate ( $\mathrm{pH} 8.1$ ), 10\% ACN, and sequencing grade trypsin (Promega, $10 \mathrm{ng} / \mu \mathrm{L}$ ). Digestion was carried out overnight at $37^{\circ} \mathrm{C}$, the resulting peptides were extracted with $30 \%$ ACN $/ 0.1 \%$ trifluoroacetic acid (TFA) and subjected to mass spectrometric analysis.

Mass spectra were acquired in the positive ion mode on a MALDI-FTMS APEX-Ultra (Bruker Daltonics, Bremen, Germany) equipped with a $9.4 \mathrm{~T}$ superconducting magnet and a SmartBeam laser. The acquisition mass range was 700-3500 m/ $\mathrm{z}$ and 512k data points were collected. A $280 \mathrm{~V}$ potential was applied to the MALDI plate. The cell was opened for $2500 \mathrm{~ms}, 4$ experiments were collected for one spectrum, where one experiment corresponds to 300 laser shots. The instrument was externally calibrated using PepMix II peptide standard (Bruker Daltonics, Bremen, Germany), resulting in a typical mass accuracy below 2 ppm. A saturated solution of $\alpha$-cyano-4-hydroxy-cinnamic acid in 50\% 
ACN/0.2\% TFA was used as a MALDI matrix. $1 \mu \mathrm{L}$ of matrix solution was mixed with 1 $\mu \mathrm{L}$ of the sample on the target and the droplet was allowed to dry at ambient temperature. After analysis, the spectra were apodized using square sin apodization with one zero fill. The interpretation of mass spectra was performed using DataAnalysis version 3.4 and BioTools 3.2 software packages (Bruker Daltonics, Billerica, MA, USA). Proteins were identified by peptide mass fingerprinting (PMF) using the search algorithm MASCOT (Matrix Science, Boston, MA, USA).

The characteristic spectrum was matched to the complete genome of C. paraputrificum J4. For purified crChit62J4 the characteristic spectrum was matched reliably with predicted fragments of putative chitinase from the bacterial genome (peg1890, Supplementary Figure S2).

\subsection{MALDI-TOF Analysis}

The crude enzyme crChit62J4 in $0.05 \mathrm{M}$ Tris $/ \mathrm{HCl}, \mathrm{pH} 8$, at a concentration of $1 \mathrm{mg} / \mathrm{mL}$ was subjected to matrix-assisted laser desorption/ionization-time of flight (MALDI-TOF) mass spectroscopy analysis (Supplementary Figure S3) with a BIFLEX III spectrometer (Bruker).

\subsection{Activity Assay}

Substrate specificity was determined using substrates 4-nitrophenyl-N-acetyl- $\beta$-Dglucosaminide (pNG), 4-nitrophenyl- $N, N^{\prime}$-diacetyl- $\beta$-D-chitobioside (pNGG), and 4-nitrophenyl- $\beta-\mathrm{D}-N, N^{\prime}, N^{\prime \prime}$-triacetylchitotrioside (pNGGG). The reaction mixture with a total volume of $80 \mu \mathrm{L}$ containing pure enzyme at concentration $2.7 \mu \mathrm{g} / \mathrm{mL}$, substrate at concentration $2 \mathrm{mM}$, and Assay buffer (60 $\mu \mathrm{L}$, Sigma-Aldrich, St Louis, MO, USA, A4855) was incubated at $37^{\circ} \mathrm{C}$ and the reaction was stopped by the addition of $0.4 \mathrm{M} \mathrm{Na}_{2} \mathrm{CO}_{3}$ $(40 \mu \mathrm{L})$ after $45 \mathrm{~min}$. Increase of optical density at $405 \mathrm{~nm}$ was measured with respect to background readings for identical mixtures without enzyme.

The effects of $\mathrm{pH}$ on activity, optimum temperature and kinetic parameters were measured using pNGG and standard assay conditions. The $\mathrm{pH}$ optimum was found using $0.1 \mathrm{M}$ citric acid-potassium phosphate buffer ( $\mathrm{pH}$ 3-7), $0.1 \mathrm{M}$ potassium phosphate buffer (pH 6-8) and $0.1 \mathrm{M}$ glycine buffer ( $\mathrm{pH}$ 9-10). The temperature optimum was determined in the range of $40-90^{\circ} \mathrm{C}$ in $0.1 \mathrm{M}$ citric acid-potassium phosphate, $\mathrm{pH}$ 5.5.

Kinetic parameters were calculated from initial rate parameters with concentrations of pNGG from 0.02 to $4.2 \mathrm{mM}$ in $0.1 \mathrm{M}$ citric acid-potassium phosphate buffer $\mathrm{pH} 5.5$, and incubation time $30 \mathrm{~min}$ (linear increase was observed in the first $70 \mathrm{~min}$ of reaction). $K_{\mathrm{m}}$ and $k_{\text {cat }}$ were calculated from an average of three measurements according to the MichaelisMenten equation. The kinetics interpretation and fitting were performed using GraphPad Prism version 7.02 for Windows (GraphPad Software, La Jolla California USA, www. graphpad.com). Activity on colloidal chitin was checked using $0.5 \%(w / v)$ carboxymethyl chitin as a substrate according to Inglis and Peberdy [26].

The influence of selected compounds on the activity and kinetic parameters were investigated. The protein sample was pre-incubated with each reagent in the reaction buffer at room temperature for $20 \mathrm{~min}$. Then, it was used to measure the change in activity and Michaelis-Menten dependence as described above. The final concentration of the reagent in the reaction was $5 \mathrm{mM}$.

\subsection{TLC}

Thin-layer chromatography (TLC) was used to analyze the reaction products with chitin, chitohexaose, and CM-chitin as substrates. Aliquots of the reaction mixtures were chromatographed on a silicagel sheet (ALUGRAM SIL G Art.Nr. 818163, Thermo Fisher Scientific, Waltham, MA, USA) with $n$-butanol-methanol-25\% ammonia solution-water (volume ratio 5:4:2:1). The products were developed using a spray containing anilinediphenylamine reagent ( $4 \mathrm{~mL}$ of aniline, $4 \mathrm{~g}$ of diphenylamine, $200 \mathrm{~mL}$ of acetone, and 
$30 \mathrm{~mL}$ of phosphoric acid) and baking the sheet at $180^{\circ} \mathrm{C}$ for $3 \mathrm{~min}$ [27]. For the raw TLC data see the photographs of the TLC plates (Supplementary Figure S4).

\subsection{Dynamic Light Scattering}

Particle size distribution was assessed using dynamic light scattering (DLS, Malvern Instruments, ZEN3600) in a $45-\mu \mathrm{L}$ glass cuvette at $18{ }^{\circ} \mathrm{C}$ with enzyme concentration $1.0 \mathrm{mg} / \mathrm{mL}$ in $50 \mathrm{mM} \mathrm{KH}_{2} \mathrm{PO}_{4} / \mathrm{K}_{2} \mathrm{HPO}_{4}, 1 \mathrm{mM} \mathrm{NaN}_{3}, \mathrm{pH}$ 7.0. MW was estimated using the empirical mass vs. size calibration curve (Dispersion Technology Software 5.03, Malvern Instruments).

\subsection{Determination of Protein Concentration}

Protein concentration was estimated based on UV spectrophotometry at $\lambda=280 \mathrm{~nm}$ in $1 \mathrm{~cm}$ path-length quartz cuvette, using a Libra 22 UV-VIS spectrophotometer (Biochrom, United Kingdom) with background reading for a given buffer and a theoretical extinction coefficient based on the protein sequence.

\subsection{Sequence Analysis and Computer Modeling}

Sequence searches were performed using the BLAST service $[28,29]$. Sequence alignments were performed with ClustalX and ClustalW using the Gonnet 250 weight matrix [30]. Enzyme domains were modeled using the SwissModel server, ProMod3 3.2.0 [31]. Models were calculated based on automated or manual lead selection and preselected homologous domains identified by sequence search. Models with an overall QMEAN4 global score greater than 0.6 were accepted [32].

\section{Results}

Anaerobic cultivation yielded approximately $0.5 \mathrm{mg}$ of crChit62J4 per liter of culture, after purification providing $\sim 0.1 \mathrm{mg}$ of protein per liter of initial culture volume. The identity and purity of crChit62J4 were confirmed by MS analysis and reliable sequence match. The Chit62J4 gene codes for 601 amino acids with a total theoretical MW $=65414.9$ and $\mathrm{pI}=5.81$ (Figure 1, Supplementary Figure S5). This includes a signal sequence identified by the prediction services as residues $1-29$, i.e., the $N$-terminus of the mature enzyme sequence being AQSL [33,34].

The theoretical mass of mature Chit62J4 (residues 30-601) of 62284.9 and pI of 5.2 correspond to the experimental values for crChit62J4: 62.4 kDa (MALDI-TOF, Supplementary Figure S3) and pI of 4.9 (chromatofocusing). The DLS results for crChit62J4 indicate a monodisperse solution with hydrodynamic radius $3.65 \mathrm{~nm}$ ( $130 \mathrm{kDa}$ for globular protein) corresponding to a dimer of Chit62J4. If Chit62J4 had an extremely elongated shape, it may also roughly correspond to a monomer of the enzyme.

Crude Chit62J4 is active on pNGG and pNGGG (against pNGGG $~ 10 \times$ lower, data not shown), with no activity toward pNG. On these chromogenic substrates, the enzyme performs mostly as an exochitinase, on pNGG exhibiting $k_{\text {cat }} 13.5 \mathrm{~s}^{-1}, K_{\mathrm{m}}=0.57 \mathrm{mM}$ and catalytic efficiency $k_{\text {cat }} / K_{\mathrm{m}}=23,684 \mathrm{M}^{-1} \mathrm{~s}^{-1}$, optimal $\mathrm{pH} 5.5$ and temperature $60{ }^{\circ} \mathrm{C}$ (Supplementary Figure S6). The enzyme is also active on colloidal chitin. In the presence of standard antimycotics Griseofulvin, Amfotericine, and Clotrimazole ( $5 \mathrm{mM})$ it retains its full activity.

The predicted membrane translocation signal sequence at the $\mathrm{N}$-terminus of the native Chit62J4 is followed by an amino acid sequence corresponding to a four-domain protein. Based on the sequence alignment with other known chitinases (Supplementary Figure S7), we propose the following domain structure of mature Chit62J4: the N-terminal catalytic domain, two re-iterated Fn3/Big3 domains, and the C-terminal chitin binding module ChtBD3 (chitin-binding domain type 3). The overall structure resembles that of chitinase Chi18C from Clostridium paraputrificum M21 [35]. 


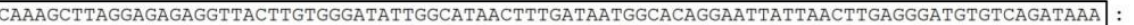

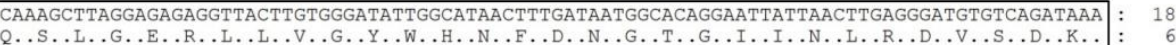

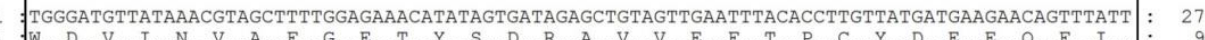

TTACAAGCATCAGATACAGATTTCAAGAATCCTAAAACACCACAAATAGTTAATCTTATTTCAGGTGTAAGGGAAATATCTGATAAATAT

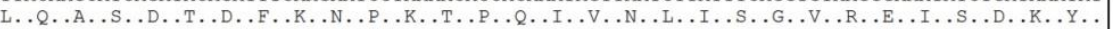

TATACACAAGGAACAGCAGATTATGAAGTAGCAATGGCAGAAATGCTTTTATATGGATTTCCTATAGCAGGTAATAGTAATAATATGTTC

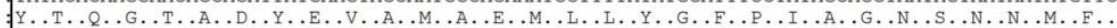

CCAGCTTTAAGAGAAGACCAAGTTATGATTGGATTGCCAGCAACTCAGGCTGCTGCACCAAGTGGTGGATATATAAATCCAACAGAAATG

TTAATGACATGGTCTATTAATTGGGATGCTAAAAATAATTTTGAGTTTTCTAATAATTATAGAGATTACTTTGATAAACTAACTCCAGTT

N. H. F. catalytic

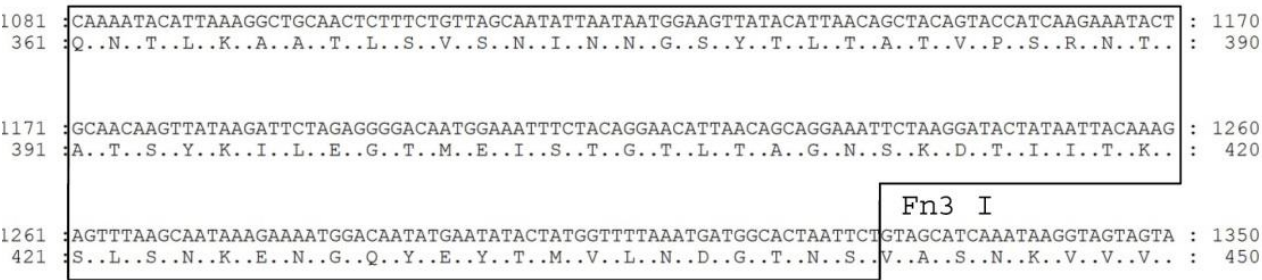

$1351:$ AAGGTAGAACCTCAACCAGAACTTACATTAAAAGCTGCAACATTATCAGCTAGCGCTGTTAATAATGGAAATTATACTCTATCAGCTATA: 1440

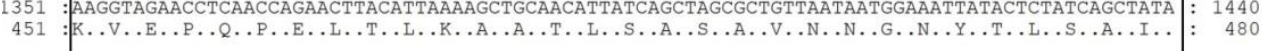
$1441:$

GTTCCTGAATATAATAAGGCAACAAGTTATAAAATTCTTGAAGGAAGTATAGAAGTAGCTTCAGGTACATTAAATGCTGGTAATAGTGA

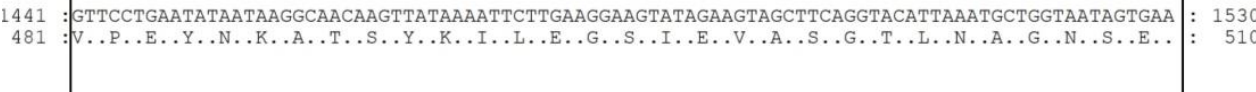

1531 :CAAGTAACTCTTACAAAAAAAATCACAAATAAAGAGATTGGTAGCTATAATTACACAGTTGTTCTTTATGAAGGAGCAAATTCTGTTATA: 1620

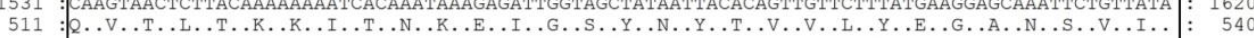

Fn3 II

$1621:$ TCAAATAAAGTAACTGTTGTAGTA GAAAACTACACACCAGAGGTCCAA GCTTGGGCAGCTTATGTAGCATATAAAAATGGTGATATAGTA : 1710

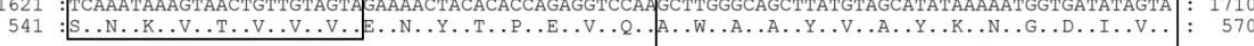

$1711:$ AGTTATAATGGAAGCAATTATGTTTGTAGACAGGCTCACACATCTTTACCAGGATGGGAGCCAACTAATGTAGCAGCATTATGGCAAAAA : 1800

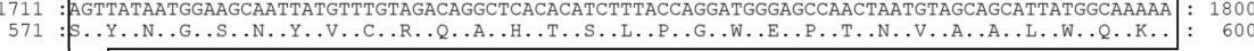

Figure 1. DNA and amino acid sequence of chitinase Chit62J4. The expected domain boundaries and catalytic amino acids are marked. The construct boundaries of rChit62J4 and rChit62J4cat are marked with filled and line arrows, respectively. 
The kinetic parameters for both rChit62J4 and rChit62J4cat toward pNGG were determined as $K_{m}=0.24 \pm 0.02 \mathrm{mM}, k_{\text {cat }}=31.5 \pm 0.9 \mathrm{~s}^{-1}$ and $K_{m}=0.19 \pm 0.02 \mathrm{mM}$, $k_{\text {cat }}=31.4 \pm 0.8 \mathrm{~s}^{-1}$, respectively. The influence of several groups of compounds expected to affect activity was tested. In the case of the catalytic domain, the substrate affinity increased slightly compared to the complete mature enzyme. The affinity also increased in the presence of $5 \mathrm{mM} \mathrm{MgCl} 2,5 \mathrm{mM}$ EDTA, $5 \mathrm{mM} \mathrm{ZnSO}_{4}$, and $5 \mathrm{mM} \mathrm{CaCl}_{2}$ (Table 1; Supplementary Figures S8 and S9). Conversely, the substrate affinity decreased in the presence of $5 \mathrm{mM}$ glucosamine or $5 \mathrm{mM}$ glucose. The TLC results showed that both the intact enzyme and its catalytic domain cleaved chitohexaose as well as colloidal chitin producing chitobiose as the end product (Supplementary Figure S4).

Table 1. Kinetic parameters of rChit62J4 influenced by selected compounds. Standard deviations are given.

\begin{tabular}{cccc}
\hline Enzyme & Compound Added into the Reaction Trial & $\boldsymbol{k}_{\text {cat }}\left(\mathbf{s}^{-\mathbf{1}}\right)$ & $\boldsymbol{K}_{\mathbf{m}}(\mathbf{m M})$ \\
\hline rChit62J4 & none & $31.5 \pm 0.9$ & $0.24 \pm 0.02$ \\
\hline & $5 \mathrm{mM}$ glucosamine & $30.2 \pm 0.9$ & $0.36 \pm 0.04$ \\
& $5 \mathrm{mM} \mathrm{glucose}^{*} \mathrm{mM} \mathrm{MgCl}_{2}$ & $31.2 \pm 0.9$ & $0.36 \pm 0.04$ \\
rChit62J4 & $5 \mathrm{mM} \mathrm{EDTA}$ & $29.6 \pm 0.6$ & $0.18 \pm 0.02$ \\
& $5 \mathrm{mM} \mathrm{ZnSO}_{4}$ & $31.9 \pm 0.8$ & $0.19 \pm 0.02$ \\
& $5 \mathrm{mM} \mathrm{CaCl}_{2}$ & $31.1 \pm 0.6$ & $0.16 \pm 0.01$ \\
rChit62J4cat & none & $30.3 \pm 0.6$ & $0.14 \pm 0.01$ \\
\hline
\end{tabular}

\section{Discussion}

\subsection{Sequence and Structure of Chit62J4}

The most abundant extracellular enzyme of Clostridium paraputrificum $\mathrm{J} 4$ is chitinase Chit62J4 with predominant exochitinolytic activity and belonging to the GH18 family with the retaining mechanism. Mature Chit62J4 comprises four domains: the catalytic domain, two copies of a Fn3 domain, and the carbohydrate-binding module ChtBD3 (chitin-binding domain 3). This domain structure is not uncommon in chitinases, the most similar enzyme being Chi18C from Clostridium paraputrificum M21, however, with different catalytic domain and specificity. A sequence search against known structures in the Protein Data Bank does not provide significant hits.

The catalytic domain of Chit62J4 shares the highest sequence identity (79\%) with single domain chitinase D from Clostridium botulinum B str. Eklund 17B (NCBI YP_001885576.1). Of the chitinases with known 3D structures, the catalytic domain of Chit62J4 shows the highest similarity (75\% identity) to the single domain chitinase ChiNCTU2 from Bacillus cereus NCTU2 [36]. Thus, while the complete domain structure of Chit62J4 most resembles that of Chi18C, the catalytic properties should resemble those of ChiNCTU2. The explanation for this "catalytic domain replacement" remains elusive. The accessory domains likely contribute to better binding and directionality of the substrate with respect to the catalytic site and support catalysis on fibers.

The 90-residue Fn3/Big3 domains (residues 363-442 and 449-548) share 63\% identity and show $44-57 \%$ identity to the closest homologous sequences in chitinases, e.g., in Chi18C. Pfam [37] classifies the first Fn3 domain into the Cadherin family or family DUF4397 ("domain of unknown function in bacteria, archaea, and eukaryotes") and the second domain as part of the CARDB family ("cell adhesion domain found in bacteria"). In our general sequence search against all protein records, the first Fn3 domain is most similar to two domains from Clostridium beijerinckii NCIMB 8052 carbohydrate-binding family V/XII protein (residues 229-317, 58\% identity and 135-222, 49\%). The second domain search leads to similar results. The complete two-domain sequence does not produce any significant hits, making the Fn3-Fn3 combination of domains in Chit62J4 unique. 
The C-terminal domain ChtBD3 (557-601) is 60\% identical with a carbohydratebinding module of chitinase A1 from Bacillus circulans [38], a domain found by Hashimoto et al. [39] to enhance the enzymatic activity by interaction with insoluble chitin, while its interaction with soluble chitin or chitin derivatives was not observed.

\subsection{Molecular and Catalytic Properties of Chit62J4}

The isolated enzyme is present in solution in the form of monomers or dimers and its highest activity against pNGG compared to longer and shorter substrates characterizes it as a chitinase with predominant exochitinolytic activity. Its $K_{\mathrm{m}}$ and $k_{\text {cat }}$ values are comparable to those of other chitinases (Table 2). The enzyme is active in $\mathrm{pH}$ range 3.5-7 with an optimum at $\mathrm{pH} 5.5$. The optimal activity temperature of $60^{\circ} \mathrm{C}$ indicates a highly stable enzyme, compared to other chitinases of similar sequence and structure. The absence of the non-catalytic domains in Chit62J4cat shifted the $\mathrm{pH}$ optimum to more acidic 5.0 (Supplementary Figure S6).

Table 2. Comparison of activity of chitinolytic enzymes related to Chit62J4.

\begin{tabular}{|c|c|c|c|c|c|c|c|c|c|c|}
\hline Enzyme & Organism & $\begin{array}{c}M_{\mathrm{r}} \\
\text { kDa }\end{array}$ & $\begin{array}{c}\text { Stability } \\
\text { Range } \\
\text { pH }\end{array}$ & $\begin{array}{l}\text { Optimal } \\
\text { pH, Tem- } \\
\text { perature }\end{array}$ & $\begin{array}{c}\text { Substrate } \\
\text { Type and } \\
\text { Assay } \\
\text { Conditions }\end{array}$ & $\begin{array}{l}K_{\mathrm{m}} \\
(\mu \mathrm{M})\end{array}$ & $\underset{V_{\max }}{(\mu \mathrm{mol} / \mathrm{min} / \mathrm{mg})}$ & $\begin{array}{l}\text { Activity } \\
\text { Type }\end{array}$ & Inhibitors & Reference \\
\hline Chitinase A & $\begin{array}{l}\text { Clostridium } \\
\text { paraputrificum } \\
\text { M-21 }\end{array}$ & 89.0 & $6-9$ & $6,45^{\circ} \mathrm{C}$ & $\begin{array}{l}\text { pNGG, pH } \\
6,37^{\circ} \mathrm{C}\end{array}$ & 6.9 & 43.0 & Exo & $\begin{array}{c}1 \mathrm{mM} \mathrm{HgCl} \mathrm{Hg}_{2} \\
\text { Partly: } \mathrm{AlCl}_{3} \text {, } \\
\mathrm{CaCl}_{2}, \mathrm{CuCl}_{2}, \\
\mathrm{FeCl}_{3}, \mathrm{MnCl}_{2} \\
\text { Enhanced: } \mathrm{MgCl}_{2}\end{array}$ & $\begin{array}{l}\text { Morimoto } \\
\text { et al. [40] }\end{array}$ \\
\hline Chitinase B & $\begin{array}{l}\text { Clostridium } \\
\text { paraputrificum } \\
\text { M-21 }\end{array}$ & 86.5 & $6-9$ & $6,45^{\circ} \mathrm{C}$ & $\begin{array}{l}\text { pNGG, pH } \\
7,37^{\circ} \mathrm{C}\end{array}$ & 6.3 & 46.0 & Exo & $\begin{array}{c}1 \mathrm{mM} \mathrm{HgCl}_{2} \\
\text { Partly: } \mathrm{AlCl}_{3}, \\
\mathrm{CuCl}_{2}, \mathrm{FeCl}_{3}, \\
\mathrm{No} \mathrm{Effect:} \mathrm{MgCl}_{2}, \\
\mathrm{CaCl}_{2}, \text { EDTA }\end{array}$ & $\begin{array}{l}\text { Morimoto } \\
\text { et al. [41] }\end{array}$ \\
\hline Chitinase C & $\begin{array}{l}\text { Clostridium } \\
\text { paraputrificum } \\
\text { M-21 }\end{array}$ & 72.0 & NA & $6,60^{\circ} \mathrm{C}$ & $\begin{array}{c}\text { pNGGG, } \\
\text { pH 6, } 50^{\circ} \mathrm{C}\end{array}$ & 0.44 & 26.6 & Endo & & $\begin{array}{l}\text { Morimoto } \\
\text { et al. [35] }\end{array}$ \\
\hline $\begin{array}{l}\mathrm{N} \text {-acetylgluc } \\
\text { osaminidase }\end{array}$ & $\begin{array}{l}\text { Clostridium } \\
\text { paraputrificum } \\
\text { M-21 }\end{array}$ & 45.5 & $6-9$ & $7,50^{\circ} \mathrm{C}$ & $\begin{array}{l}\text { pNG, pH 7, } \\
37^{\circ} \mathrm{C}\end{array}$ & 7.9 & 21.8 & NAGase & & Li et al. [42] \\
\hline rChit62J4 & $\begin{array}{l}\text { Clostridium } \\
\text { paraputrificum } \\
\mathrm{J} 4\end{array}$ & 62.3 & & $5.5,60^{\circ} \mathrm{C}$ & $\begin{array}{l}\text { pNGG, pH } \\
5.5,37^{\circ} \mathrm{C}\end{array}$ & 240 & 29.0 & Exo & $\begin{array}{c}5 \mathrm{mM} \mathrm{MnSO}_{4} \\
\mathrm{ZnSO}_{4}, \mathrm{FeCl}_{2} \\
\mathrm{HgCl}_{2}\end{array}$ & This work \\
\hline ChiNCTU2 & $\begin{array}{l}\text { Bacillus cereus } \\
\text { NCTU2 }\end{array}$ & 36.2 & $6-8$ & $\begin{array}{c}7.0 \\
50-60^{\circ} \mathrm{C}\end{array}$ & $\begin{array}{l}\text { pNGG, pH } \\
6.5,25^{\circ} \mathrm{C}\end{array}$ & 74 & 34.6 & Exo & $\begin{array}{c}10 \mathrm{mM} \mathrm{Hg}^{2+} \\
\mathrm{Cu}^{2+}, \mathrm{Zn}^{2+}\end{array}$ & $\begin{array}{c}\text { Hsieh et al., } \\
\text { Wen et al., } \\
{[36,43]}\end{array}$ \\
\hline
\end{tabular}

The key catalytic residues and the nearest surrounding amino acids of Chit62J4, ChiD and ChiNCTU2 are identical (Figure 2), which suggests comparable parameters for the catalytic mechanism and kinetics. The catalytic rates of rChit62J4 and ChiNCTU2 toward pNGG were 31.5 and $20.9 \mathrm{~s}^{-1}$, respectively, which are comparable. The $K_{\mathrm{m}}$ values of $240 \mu \mathrm{M}$ (rChit62J4) and $74 \mu \mathrm{M}$ (ChiNCTU2) imply the affinity of Chit62J4 to the substrate being approximately $3 \times$ weaker and the catalytic efficiency about $4 \times$ lower. The level of sequence identity enables reliable modeling of the catalytic domain of Chit62J4. Differences between ChiNCTU2 and Chit62J4 active sites can only be found further away from the catalytic center, certainly out of the reach of substrate subunits -2 to +2 (comparison of the model with superimposed structures with PDB id 1e6r, 1e6n, 1e6z, [44]; 1ehn, [45] 3n18, $3 \mathrm{n} 12$, [36]). Therefore, the different $K_{\mathrm{m}}$ values can be attributed most likely to the dynamic behavior and the overall differences in the electrostatics of the domain. ChiNCTU2 adjusts the conformation of the loop 85-88 at substrate binding. This requires a degree of dynamic flexibility, possibly different in ChiNCTU2 and Chit62J4. The accessory domains of Chit62J4 most likely do not contribute to the difference in the catalytic efficiency, and they do not affect the catalytic domain functionality, as their removal did not lead to significant changes of $K_{\mathrm{m}}$ or $k_{\text {cat }}$. It is still expected, however, that the ChtBD3 domain would help to recruit and bind longer chitin or chitin-like substrates and increase the probability of contact with the Chit62J4 active site. 


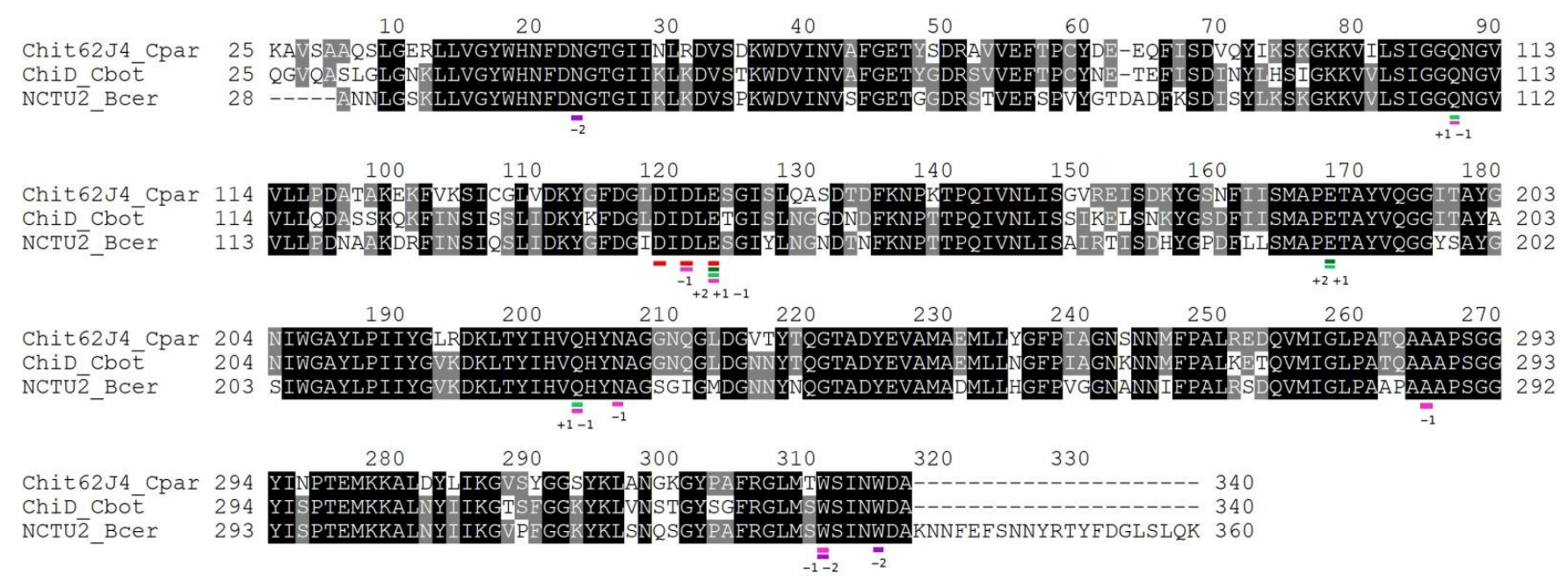

Figure 2. Sequence alignment of Chit62J4 from C. paraputrificum J4, chitinase D from C. botulinum and chitinase ChiNCTU2 from B. cereus. Identities are marked by black background. Expected catalytic residues are marked by a red line; residues forming the -2 to +2 subsites (according to Hsieh et al. [36]) of the substrate binding site are marked by colored lines and site numbering.

Based on the high sequence similarity and similar kinetics, we conclude that Chit62J4 utilizes the retaining mechanism with the catalytic residues Asp142, Asp144 and Glu146 and residues Tyr41, Phe68, and Gln110, conserved with ChiNCTU2, being the key residues for substrate binding [44]. This corresponds to the substrate-assisted catalytic mechanism of GH18 chitinases via bicyclic oxazolinium-ion intermediate [11].

\subsection{Adaptation of Clostridium Chitinase to Environment}

Chitinases of this family have optimal temperatures in a wide range of $30-60{ }^{\circ} \mathrm{C}$ and optimal pH mostly in the range 5.0-8.0 with several examples of extremes at $\mathrm{pH} 4.0$ and $9.0[35,46]$. Within related enzymes, there is no example of a chitinase with such a hightemperature stability and at the same time such a low $\mathrm{pH}$ optimum. The catalytic domains of ChiNCTU2 and Chit62J4 are highly similar and according to our structure model (see below) the core of the catalytic site should be almost identical. Their temperature optima are equal, however, the Chit62J4 $\mathrm{pH}$ optimum of 5.5 contrasts with that of ChiNCTU2 at $\mathrm{pH}$ 7.0. This significant difference is, nevertheless, in agreement with the surface electrostatics (Supplementary Figure S10) and the theoretical isoelectric points of their catalytic domains. More acidic Chit62J4 (negative surface potential, pI 4.9) has a lower $\mathrm{pH}$ optimum than ChiNCTU2 with pI 6.0. The theoretical and experimental (native conditions) pI of complete mature Chit62J4 are 5.2 and 4.9, respectively. In both enzymes, the $\mathrm{pH}$ optimum is several tenths to one degree above the respective pI. Given the high identity of the active sites, the difference in $\mathrm{pH}$ optima between ChiNCTU2 and Chit62J4 results rather from the overall protein behavior at a certain $\mathrm{pH}$ than from any particular variations in the active site. Our calculations of electrostatics distributions at the measured $\mathrm{pH}$ optima show for both ChiNCTU2 and Chit62J4 typical chitinase patterns (Supplementary Figure S10), with no significant positive potential and relatively high negative potential at the active center. Chitin chains, often partially deacetylated, can carry positive charge and positive potential near the active site would block substrate binding, while strong negative potential will lead to nonproductive binding. Calculations performed at the exchanged $\mathrm{pH}$ points for the two proteins clearly show extreme electrostatics (Supplementary Figure S10). Therefore, the optimization with respect to the acidity of the environment in these enzymes was achieved by adjusting the overall molecular electrostatics, coded by the amino acid composition (different) and three-dimensional organization (similar) without any interference directly in the active site. ChiNCTU2 originates from a soil bacterium, while Chit62J4 is active in the human colon. $\mathrm{pH}$ within a healthy human colon slowly increases from 5.5 at the 
beginning to 7.0 at its end [47]. The Roseburia/E. rectale group of bacteria in the study by Duncan et al. (2009) [6] competed well at lower $\mathrm{pH}$ for polysaccharide substrates. It follows from this that if Clostridium needs to compete for insoluble fiber substrates, it must compete at decreased $\mathrm{pH}$ in the proximal part of the colon. Thus, the optimization for chitinolytic activity at lower $\mathrm{pH}$ is in full agreement with the microbiome environmental conditions. The highest bacterial growth occurs in the first colon section, and it can be expected that C. paraputrificum $\mathrm{J} 4$ is exposed to lower $\mathrm{pH}$ than B. cereus, under competition with other microbiome bacteria. Adjustment of extracellular Chit62J4 to the acidic environment of the human colon therefore explains the differences observed on the molecular level. The Chit62J4 adaptation happened away from the actual catalytic site. Similar shifts of $\mathrm{pH}$ optima, realized by the overall protein composition rather than active site changes, were seen also in other enzymatic systems, e.g., in non-specific nucleases [48].

Utilization of carbohydrate-binding domains by commensal bacteria enzymes represents an important strategy for providing the ability to process fibrous chitin and for localization closer to the energy source, both as advantages in internal microbiome competition [1]. Chit62J4 is capable of CM-chitin degradation to chitobiose, both in its intact form rChit62J4 and as the sole catalytic domain rChit62J4cat. Chit62J4 is thus capable of adsorbing on the surface of chitin particles and processing the accessible ends of chitin fibers.

The existence of a chitinase-coding gene, which has a catalytic domain remarkably similar to a typical soil bacterium with shifted $\mathrm{pH}$ optimum and complemented by accessory domains, illustrates the adjustments needed to utilize chitin and chitin-derived compounds in the human colon. Microbiota adaptation to diet was previously also proven on the level of enzyme functionality [49]. Similarly, Clostridium paraputrificum J4 appears to have its cohort of enzymes adjusted to the gut environment.

\subsection{Role of Chit62J4}

C. paraputrificum $\mathrm{J} 4$ employs several different enzymes in the individual steps of degradation of chitin [17]. Endochitinases perform the initial steps to produce the free ends of chitin chains. Exochitinases, including Chit62J4, then process chains with free ends (possibly still attached to the fibrous substrate) into chitobiose units. N-acetylglucosaminidases produce individual GlcNAc units, which are then most likely imported and utilized by $C$. paraputrificum J4, mainly as an energy source. Under varied cultivation conditions, Chit62J4 remains at high levels and the highest of the $60 \mathrm{kDa}$ isoenzymes without dependence on cultivation parameters, which underlines its importance in the chitinolytic complex (Chit62J4 most likely corresponds to samples "III" and "C27" in previously reported isolation experiments by Dušková et al. [16] and Šimůnek et al. [23], respectively).

\subsection{Factors Influencing Activity of Chit62J4}

Mercury and iron are almost universal enzyme inhibitors and in the case of crChit62J4 $3 \%$ and $58 \%$ of activity is retained, respectively (Table 3). Inhibition is observed with $\mathrm{Mn}^{2+}$ and $\mathrm{Cu}^{2+} . \mathrm{Ca}^{2+}$ has no effect, in contrast to a $100 \%$ increase of the activity of ChiNCTU2 [43]. $\mathrm{Mg}^{2+}$ causes a small increase in affinity, which was also observed for chitinase CHIT60 from Serratia plymuthica HR0-C48 [50] and a $60 \mathrm{kDa}$ chitinase from Bacillus sp.13.26 [51]; ChiNCTU2 was not affected (Table 4). The exchanged effects of $\mathrm{Ca}^{2+}$ and $\mathrm{Mg}^{2+}$ on the two highly similar active sites (Chit62J4 vs. ChiNCTU2) can be explained only by differences in the overall composition/structure and not by direct effects on the active site as the direct participation of metals in the mechanism can be excluded (no effect of $5 \mathrm{mM}$ EDTA) and the active centers are identical. Binding of $\mathrm{Mg}^{2+}$ was reported in two chitinase structures [52], however, without any explanation of the role in catalysis. 
Table 3. Inhibition data for crChit62J4. Measured with $2 \mathrm{mM}$ pNGG as a substrate, $2.7 \mu \mathrm{g} / \mathrm{mL}$ crChit62J4, at $37^{\circ} \mathrm{C}$ and $\mathrm{pH}$ 5.5. The relative values of activity compared to values without added compounds under the same conditions and standard deviations are given.

\begin{tabular}{cccc}
\hline Inhibitor & \% Activity \\
\hline $5 \mathrm{mM} \mathrm{MnSO}_{4} \cdot \mathrm{H}_{2} \mathrm{O}$ & 52 & \pm & 6 \\
$5 \mathrm{mM} \mathrm{CuSO}_{4} \cdot 5 \mathrm{H}_{2} \mathrm{O}$ & 89 & \pm & 9 \\
$5 \mathrm{mM} \mathrm{FeCl}_{2} \cdot 4 \mathrm{H}_{2} \mathrm{O}$ & 58 & \pm & 4 \\
$5 \mathrm{mM} \mathrm{HgCl}_{2}$ & 3 & \pm & 4 \\
$5 \mathrm{mM} \mathrm{Griseofulvin}$ & 104 & \pm & 27 \\
$5 \mathrm{mM} \mathrm{Amfotericine}$ & 119 & \pm & 4 \\
$5 \mathrm{mM} \mathrm{Clotrimazole}$ & 102 & \pm & \\
\hline
\end{tabular}

Table 4. Inhibition and stimulation effects in selected chitinases. Inhibitor concentration was $5 \mathrm{mM}$ unless a different value is given in brackets. Percentage of original activity is given. Values marked with * are the mean values for substrate concentration $3.5 \mathrm{mM}$ from kinetics in this work.

\begin{tabular}{|c|c|c|c|c|c|c|c|c|c|c|c|}
\hline Organism, Reference & $\begin{array}{c}\text { Serratia } \\
\text { plymuthica } \\
\text { HR0-C48 [50] }\end{array}$ & $\begin{array}{c}\text { Serratia } \\
\text { plymuthica } \\
\text { HR0-C48 [50] }\end{array}$ & $\begin{array}{l}\text { Scorpaena } \\
\text { scrofa }[53]\end{array}$ & $\begin{array}{l}\text { Bacillus cereus } \\
\text { NCTU2 [43] }\end{array}$ & $\begin{array}{l}\text { Enterobacter } \\
\text { sp. G-1 } \\
\text { [54] }\end{array}$ & $\begin{array}{c}\text { Alcaligenes } \\
\text { xylosoxydans } \\
\text { [55] }\end{array}$ & $\begin{array}{c}\text { Bacillus } \\
\text { sp. 13.26 } \\
\text { [51] }\end{array}$ & $\begin{array}{l}\text { Bacillus sp. } \\
\text { BG-11 [56] }\end{array}$ & $\begin{array}{l}\text { Clostridium } \\
\text { sp. JM2 [57] }\end{array}$ & $\begin{array}{l}\text { Clostridium } \\
\text { sp. JM2 [57] }\end{array}$ & This Work \\
\hline Enzyme, MW (kDa) & Chit60, 60 & Chit100, 100 & Chit50, 50 & ChiNCTU2, 36 & ChiA, 60 & Chitinase, 45 & $\begin{array}{c}\text { Chitinase, } \\
60\end{array}$ & $\begin{array}{l}\text { Chitinase, not } \\
\text { given }\end{array}$ & $\begin{array}{l}\text { Purified } \\
\text { chitinolytic } \\
\text { complex }\end{array}$ & $\begin{array}{l}\text { Purified } \\
\text { chitinolytic } \\
\text { complex }\end{array}$ & $\begin{array}{c}\text { Chit62J4, } \\
62\end{array}$ \\
\hline $\begin{array}{l}\text { Substrate, (concentration } \\
\text { if known, } \mathrm{mM} \text { ) }\end{array}$ & pNGG (10) & pNG (10) & Chitin (5) & Chitin (10) & Chitin (10) & Chitin & Chitin & Chitin & pNG (10) & $\begin{array}{l}\text { Colloidal } \\
\text { chitin (10) }\end{array}$ & pNGG (2) \\
\hline $\mathrm{Mn}^{2+}$ & 250 & 55 & 145 & 100 & & & 0 & & 10 & 10 & 52 \\
\hline $\mathrm{Ca}^{2+}$ & 120 & 50 & 66 & 200 & 105 & 100 & 50 & 120 & & & $97 *$ \\
\hline $\mathrm{Cu}^{2+}$ & 10 & 0 & 103 & 5 & & 25 & & & 20 & 12 & 89 \\
\hline $\mathrm{Mg}^{2+}$ & 115 & 90 & 61 & 100 & & 100 & 131 & & 110 & 77 & $89 *$ \\
\hline $\mathrm{Hg}^{2+}$ & & & 0 & 5 & & & 0 & 50 & 0 & 0 & 3 \\
\hline $\mathrm{Co}^{2+}$ & 150 & 5 & 325 & & & & & 50 & & & \\
\hline $\mathrm{Zn}^{2+}$ & & & 111 & & & & & & 10 & 27 & $98 *$ \\
\hline $\mathrm{Ba}^{2+}$ & & & 90 & 100 & & 100 & & & & & \\
\hline $\mathrm{Cr}^{2+}$ & & & & 100 & & & & & & & \\
\hline $\mathrm{Fe}$ & & & 85 & & & & & & 0 & 0 & 58 \\
\hline $\mathrm{K}^{+}$ & & & 128 & & & & & & 100 & 75 & \\
\hline $\mathrm{Ag}^{+}$ & & & 15 & & & & & 50 & 14 & 6 & \\
\hline $\mathrm{Na}^{+}$ & $100<0.5 \mathrm{M}>$ & $100<0.5 \mathrm{M}>$ & & & 100 & 25 & & & & & \\
\hline $\mathrm{Ni}^{2+}$ & & & & & & & 116 & 120 & & & \\
\hline EDTA & & & & & 58 & & & 50 & 0 & 40 & $97 *$ \\
\hline
\end{tabular}

\subsection{Potential Application with Antimycotics}

As suggested by Davies and Pope [58], chitinases can be applied with low molecular weight antimycotics. Cell walls of pathogens causing mycoses, such as Candida albicans and dermatophytes Microspora, Trichophyton, and Epidermophyton [59-61] include chitin and often also mannan. Enzymatically damaged walls would be more easily penetrated by standard antimycotics, which will increase the efficiency of treatment. For such applications, the formulation of a combination of non-interfering enzymes with standard drugs would be necessary. Chit62J4 is a suitable candidate as antimycotics do not influence its activity.

Clostridium paraputrificum J4 secretes its main GH18 chitinase Chit62J4, relying on a catalytic domain optimized for low $\mathrm{pH}$ and accessory domains important for fibrous substrate degradation. Chitinases with highly homologous catalytic domains show significantly different parameters of catalysis (ChiNCTU2 and Chit62J4). Thus, catalytic properties cannot be reduced to the properties of the catalytic domains and of the active site but depend on the build-up of the whole protein and possibly on the dynamics of enzyme-substrate interactions as well. The results show the potential for fine-tuning of the catalytic properties of a chitinase for biotechnological applications as well as for tailored drug delivery systems relying on chitinolytic activity in the gastrointestinal tract. For potential applications in antifungal cocktails, standard antimycotics would not interfere with the catalytic activity of Chit62J4, which can be targeted against the chitin components in the fungal cell wall.

Supplementary Materials: Electronic supplementary material is available: Figure S1: SDS-PAGE of the reported proteins. Figure S2: Peptide mass fingerprinting data for crChit62J4. Figure S3: MALDI-TOF spectrum of crChit62J4. Figure S4: TLC raw data. Figure S5: Sequence records of 
Chit62J4. Figure S6: Graphs of $\mathrm{pH}$ and temperature dependence of crChit62J4 activity and $\mathrm{pH}$ dependence of rChit62J4cat activity. Figure S7: Proposed domain structure of Chit62J4. Figure S8: Michaelis-Menten kinetics curves for Chit62J4 in the presence of selected compounds. Figure S9: Overlay of Chit62J4 kinetics in the presence of selected compounds. Figure S10: Electrostatic surface potential of the catalytic domain of Chit62J4 and chitinase ChiNCTU2. Table S1: Oligonucleotides applied for PCR amplification of rChit62J4 and rChit62J4cat.

Author Contributions: Conceptualization, J.D. (Jan Dohnálek); Methodology, J.Š., J.D. (Jarmila Dušková), P.K. and P.N.; Investigation, J.D. (Jan Dohnálek), J.D. (Jarmila Dušková), G.T., and T.S.; Data Curation, J.D.(Jan Dohnálek), J.D. (Jarmila Dušková), G.T. and J.Š.; Writing-Original Draft Preparation, J.D. (Jan Dohnálek), J.D. (Jarmila Dušková), P.N., P.K. and J.Š.; Writing-Review and Editing, J.D. (Jan Dohnálek), J.D. (Jarmila Dušková), and G.T.; Visualization, J.D. (Jan Dohnálek), J.D. (Jarmila Dušková), and K.F.; Supervision, J.D.(Jan Dohnálek); Project Administration, J.D. (Jan Dohnálek); Funding Acquisition, J.D. (Jan Dohnálek). All authors have read and agreed to the published version of the manuscript.

Funding: This work was supported by the Ministry of Education, Youth and Sports of the Czech Republic support to the CIISB core facilities of the Centre of Molecular Structure, part of InstructERIC, Crystallization of Proteins and Nucleic Acids, Biophysics, and Structural Mass Spectrometry core facilities (nos. LM2015043 and LM2018127), by the European Regional Development Fund (BIOCEV, no. CZ.1.05/1.1.00/02.0109 and ELIBIO, no. CZ.02.1.01/0.0/0.0/15_003/0000447), the Czech Science Foundation (20-12109S), and by the Czech Academy of Sciences (RVO: 86652036).

Institutional Review Board Statement: Not applicable.

Informed Consent Statement: Not applicable.

Data Availability Statement: The data presented in this study are available on request from the corresponding author.

Conflicts of Interest: The authors declare no conflict of interest.

Sample Availability: Plasmids used for recombinant production of rChit62J4 and rChit62J4cat are available from the authors.

\section{Abbreviation}

$\begin{array}{ll}\text { CBM } & \text { carbohydrate binding module } \\ \text { EDTA } & \text { ethylendiaminetetraacetic acid } \\ \text { GH } & \text { glycosyl hydrolase } \\ \text { GlcNAc } & \text {-acetylglucosamine } \\ \text { PES } & \text { polyethersulfone } \\ \text { SDS } & \text { sodium dodecyl sulfate } \\ \text { MALDI-TOF } & \text { Matrix-assisted laser desorption/ionization-time of flight } \\ \text { CAN } & \text { acetonitrile } \\ \text { TFA } & \text { trifluoroacetic acid } \\ \text { MALDI-FTMS } & \text { Matrix-assisted laser desorption/ionization-Fourier transform mass spectrometry } \\ \text { PMF } & \text { peptide mass fingerprinting } \\ \text { CM-chitin } & \text { carboxymethyl chitin } \\ \text { MS } & \text { mass spectrometry } \\ \text { DLS } & \text { Dynamic light scattering } \\ \text { Fn3 } & \text { Fibronectin type 3 } \\ \text { ChtBD3 } & \text { chitin-binding domain type 3 } \\ \text { PDB } & \text { Protein Data Bank } \\ \text { pNG } & \text { 4-nitrophenyl-N-acetyl- } \beta \text {-D-glucosaminide } \\ \text { pNGG } & \text { 4-nitrophenyl N } \\ \text { pNGGG } & \text { 4-nitrophenyl- } \beta \text {-D- } N \text {, } N^{\prime}, N^{\prime \prime} \text {-triacetylchitotrioside } \\ \text { The nucleotide and amino acid sequences of Chit62J4 are available in the GenBank database under } \\ \text { accession code KX353699. }\end{array}$




\section{References}

1. Flint, H.J. Polysaccharide breakdown by anaerobic microorganisms inhabiting the mammalian gut. Adv. Appl. Microbiol. 2004, 56, 89-120. [PubMed]

2. Flint, H.J.; Bayer, E.A.; Rincon, M.T.; Lamed, R.; White, B.A. Polysaccharide utilization by gut bacteria: Potential for new insights from genomic analysis. Nat. Rev. Microbiol. 2008, 6, 121-131. [CrossRef]

3. Lopez-Santamarina, A.; Mondragon, A.D.C.; Lamas, A.; Miranda, J.M.; Franco, C.M.; Cepeda, A. Animal-origin prebiotics based on chitin: An alternative for the future? A critical review. Foods 2020, 9, 782. [CrossRef]

4. Simunek, J.; Kopecny, J.; Hodrova, B.; Bartonova, H. Identification and characterization of Clostridium paraputrificum, a chitinolytic bacterium of human digestive tract. Folia Microbiol. Praha 2002, 47, 559-564. [CrossRef] [PubMed]

5. Lozupone, C.A.; Hamady, M.; Cantarel, B.L.; Coutinho, P.M.; Henrissat, B.; Gordon, J.I.; Knight, R. The convergence of carbohydrate active gene repertoires in human gut microbes. Proc. Natl. Acad. Sci. USA 2008, 105, 15076-15081. [CrossRef]

6. Duncan, S.H.; Louis, P.; Thomson, J.M.; Flint, H.J. The role of $\mathrm{pH}$ in determining the species composition of the human colonic microbiota. Environ. Microbiol. 2009, 11, 2112-2122. [CrossRef] [PubMed]

7. Tan, K.; Tesar, C.; Wilton, R.; Keigher, L.; Babnigg, G.; Joachimiak, A. Novel alpha-glucosidase from human gut microbiome: Substrate specificities and their switch. FASEB J. 2010, 24, 3939-3949. [CrossRef]

8. Bhattacharya, D.; Nagpure, A.; Gupta, R.K. Bacterial chitinases: Properties and potential. Crit. Rev. Biotechnol. 2007, 27, 21-28. [CrossRef]

9. Hartl, L.; Zach, S.; Seidl-Seiboth, V. Fungal chitinases: Diversity, mechanistic properties and biotechnological potential. Appl. Microbiol. Biotechnol. 2012, 93, 533-543. [CrossRef] [PubMed]

10. Cantarel, B.L.; Coutinho, P.M.; Rancurel, C.; Bernard, T.; Lombard, V.; Henrissat, B. The carbohydrate-active EnZymes database (CAZy): An expert resource for glycogenomics. Nucleic Acids Res. 2009, 37, D233-D238. [CrossRef]

11. Lombard, V.; Golaconda Ramulu, H.; Drula, E.; Coutinho, P.M.; Henrissat, B. The carbohydrate-active enzymes database (CAZy) in 2013. Nucleic Acids Res. 2014, 42, D490-D495. [CrossRef]

12. Arimori, T.; Kawamoto, N.; Shinya, S.; Okazaki, N.; Nakazawa, M.; Miyatake, K.; Fukamizo, T.; Ueda, M.; Tamada, T. Crystal structures of the catalytic domain of a novel glycohydrolase family 23 chitinase from Ralstonia sp. A-471 reveals a unique arrangement of the catalytic residues for inverting chitin hydrolysis. J. Biol. Chem. 2013, 288, 18696-18706. [CrossRef] [PubMed]

13. Chen, W.; Jiang, X.; Yang, Q. Glycoside hydrolase family 18 chitinases: The known and the unknown. Biotechnol. Adv. 2020, 43, 107553. [CrossRef]

14. Eijsink, V.; Hoell, I.; Vaaje-Kolstada, G. Structure and function of enzymes acting on chitin and chitosan. Biotechnol. Genet. Eng. Rev. 2010, 27, 331-366. [CrossRef]

15. Zhu, Z.; Zheng, T.; Homer, R.J.; Kim, Y.K.; Chen, N.Y.; Cohn, L.; Hamid, Q.; Elias, J.A. Acidic mammalian chitinase in asthmatic Th2 inflammation and IL-13 pathway activation. Science 2004, 304, 1678-1682. [CrossRef] [PubMed]

16. Duskova, J.; Tishchenko, G.; Ponomareva, E.; Simunek, J.; Koppova, I.; Skalova, T.; Stepankova, A.; Hasek, J.; Dohnalek, J. Chitinolytic enzymes from bacterium inhabiting human gastrointestinal tract-Critical parameters of protein isolation from anaerobic culture. Acta Biochim. Pol. 2011, 58, 261-263. [CrossRef]

17. Sinha, V.R.; Kumria, R. Microbially triggered drug delivery to the colon. Eur. J. Pharm. Sci. 2003, 18, 3-18. [CrossRef]

18. Simunek, J.; Tishchenko, G.; Hodrova, B.; Bartonova, H. Effect of chitosan on the growth of human colonic bacteria. Folia Microbiol. Praha 2006, 51, 306-308. [CrossRef] [PubMed]

19. Shahidi, F.; Arachchi, J.K.V.; Jeon, Y.J. Food applications of chitin and chitosans. Trends Food Sci. Tech. 1999, 10, 37-51. [CrossRef]

20. Brown, G.D.; Denning, D.W.; Gow, N.A.; Levitz, S.M.; Netea, M.G.; White, T.C. Hidden killers: Human fungal infections. Sci. Transl. Med. 2012, 4, 165rv13. [CrossRef]

21. Prashanth, K.V.H.; Tharanathan, R.N. Chitin/chitosan: Modifications and their unlimited application potential—An overview. Trends Food Sci. Tech. 2007, 18, 117-131. [CrossRef]

22. Villapol, S. Gastrointestinal symptoms associated with COVID-19: Impact on the gut microbiome. Transl. Res. 2020, 226, 57-69. [CrossRef] [PubMed]

23. Simunek, J.; Koppova, I.; Tiscenko, G.; Dohnalek, J.; Duskova, J. Excretome of the chitinolytic bacterium Clostridium paraputrificum J4. Folia Microbiol. Praha 2012, 57, 335-339. [CrossRef] [PubMed]

24. Kopecny, J.; Hodrova, B.; Stewart, C.S. The isolation and characterization of a rumen chitinolytic bacterium. Lett. Appl. Microbiol. 1996, 23, 195-198. [CrossRef]

25. Tishchenko, G.; Simunek, J.; Bartonova, H.; Duskova, J.; Dohnalek, J.; Ponomareva, E.; Tennikova, T. Sample preparation in separation of the extracellular chitinolytic enzymes of the human intestinal bacterium Clostridium paraputrificum J4 from the culture fluids. J. Chromatogr. B Analyt. Technol. Biomed. Life Sci. 2011, 879, 2175-2178. [CrossRef]

26. Inglis, P.W.; Peberdy, J.F. Production and purification of a chitinase from Ewingella americana, a recently described pathogen of the mushroom, Agaricus bisporus. FEMS Microbiol. Lett. 1997, 157, 189-194. [CrossRef]

27. Pelletier, A.; Sygusch, J. Purification and characterization of three chitosanase activities from Bacillus megaterium P1. Appl. Environ. Microbiol. 1990, 56, 844-848. [CrossRef]

28. Altschul, S.F.; Gish, W.; Miller, W.; Myers, E.W.; Lipman, D.J. Basic local alignment search tool. J. Mol. Biol. 1990, 215, 403-410. [CrossRef] 
29. Camacho, C.; Coulouris, G.; Avagyan, V.; Ma, N.; Papadopoulos, J.; Bealer, K.; Madden, T.L. BLAST plus: Architecture and applications. BMC Bioinform. 2009, 10, 421. [CrossRef]

30. Larkin, M.A.; Blackshields, G.; Brown, N.P.; Chenna, R.; McGettigan, P.A.; McWilliam, H.; Valentin, F.; Wallace, I.M.; Wilm, A.; Lopez, R.; et al. Clustal W and clustal X version 2.0. Bioinformatics 2007, 23, 2947-2948. [CrossRef]

31. Waterhouse, A.; Bertoni, M.; Bienert, S.; Studer, G.; Tauriello, G.; Gumienny, R.; Heer, F.T.; de Beer, T.A.P.; Rempfer, C.; Bordoli, L.; et al. SWISS-MODEL: Homology modelling of protein structures and complexes. Nucleic Acids Res. 2018, 46, W296-W303. [CrossRef] [PubMed]

32. Benkert, P.; Biasini, M.; Schwede, T. Toward the estimation of the absolute quality of individual protein structure models. Bioinformatics 2011, 27, 343-350. [CrossRef]

33. Almagro Armenteros, J.J.; Tsirigos, K.D.; Sonderby, C.K.; Petersen, T.N.; Winther, O.; Brunak, S.; von Heijne, G.; Nielsen, H. SignalP 5.0 improves signal peptide predictions using deep neural networks. Nat. Biotechnol. 2019, 37, 420-423. [CrossRef] [PubMed]

34. Shen, H.B.; Chou, K.C. Signal-3L: A 3-layer approach for predicting signal peptides. Biochem. Bioph. Res. Co. 2007, 363, 297-303. [CrossRef] [PubMed]

35. Morimoto, K.; Yoshimoto, M.; Karita, S.; Kimura, T.; Ohmiya, K.; Sakka, K. Characterization of the third chitinase Chi18C of Clostridium paraputrificum M-21. Appl. Microbiol. Biot. 2007, 73, 1106-1113. [CrossRef]

36. Hsieh, Y.C.; Wu, Y.J.; Chiang, T.Y.; Kuo, C.Y.; Shrestha, K.L.; Chao, C.F.; Huang, Y.C.; Chuankhayan, P.; Wu, W.G.; Li, Y.K.; et al. Crystal structures of Bacillus cereus NCTU2 chitinase complexes with chitooligomers reveal novel substrate binding for catalysis A chitinase without chitin binding and insertion domains. J. Biol. Chem. 2010, 285, 31603-31615. [CrossRef] [PubMed]

37. Punta, M.; Coggill, P.C.; Eberhardt, R.Y.; Mistry, J.; Tate, J.; Boursnell, C.; Pang, N.; Forslund, K.; Ceric, G.; Clements, J.; et al. The Pfam protein families database. Nucleic Acids Res. 2012, 40, D290-D301. [CrossRef]

38. Ikegami, T.; Okada, T.; Hashimoto, M.; Seino, S.; Watanabe, T.; Shirakawa, M. Solution structure of the chitin-binding domain of Bacillus circulans WL-12 chitinase A1. J. Biol. Chem. 2000, 275, 13654-13661. [CrossRef]

39. Hashimoto, M.; Ikegami, T.; Seino, S.; Ohuchi, N.; Fukada, H.; Sugiyama, J.; Shirakawa, M.; Watanabe, T. Expression and characterization of the chitin-binding domain of chitinase A1 from Bacillus circulans WL-12. J. Bacteriol. 2000, 182, 3045-3054 [CrossRef] [PubMed]

40. Morimoto, K.; Karita, S.; Kimura, T.; Sakka, K.; Ohmiya, K. Characterization of Clostridium paraputrificum chitinase A from a recombinant Escherichia coli. J. Biosci. Bioeng. 2001, 92, 466-468. [CrossRef]

41. Morimoto, K.; Karita, S.; Kimura, T.; Sakka, K.; Ohmiya, K. Cloning, sequencing, and expression of the gene encoding Clostridium paraputrificum chitinase $\mathrm{ChiB}$ and analysis of the functions of novel cadherin-like domains and a chitin binding domain. J. Bacteriol. 1997, 179, 7306-7314. [CrossRef] [PubMed]

42. Li, H.; Morimoto, K.; Katagiri, N.; Kimura, T.; Sakka, K.; Lun, S.; Ohmiya, K. A novel beta-N-acetylglucosaminidase of Clostridium paraputrificum M-21 with high activity on chitobiose. Appl. Microbiol. Biot. 2002, 60, 420-427.

43. Wen, C.M.; Tseng, C.S.; Cheng, C.Y.; Li, Y.K. Purification, characterization and cloning of a chitinase from Bacillus sp NCTU2. Biotechnol. Appl. Biochem. 2002, 35, 213-219. [CrossRef]

44. Van Aalten, D.M.; Komander, D.; Synstad, B.; Gaseidnes, S.; Peter, M.G.; Eijsink, V.G. Structural insights into the catalytic mechanism of a family 18 exo-chitinase. Proc. Natl. Acad. Sci. USA 2001, 98, 8979-8984. [CrossRef] [PubMed]

45. Papanikolau, Y.; Prag, G.; Tavlas, G.; Vorgias, C.E.; Oppenheim, A.B.; Petratos, K. High resolution structural analyses of mutant chitinase A complexes with substrates provide new insight into the mechanism of catalysis. Biochemistry 2001, 40, 11338-11343. [CrossRef]

46. Dahiya, N.; Tewari, R.; Hoondal, G.S. Biotechnological aspects of chitinolytic enzymes: A review. Appl. Microbiol. Biotechnol. 2006, 71, 773-782. [CrossRef] [PubMed]

47. Cummings, J.H.; Macfarlane, G.T. The control and consequences of bacterial fermentation in the human colon. J. Appl. Bacteriol. 1991, 70, 443-459. [CrossRef] [PubMed]

48. Koval, T.; Dohnalek, J. Characteristics and application of S1-P1 nucleases in biotechnology and medicine. Biotechnol. Adv. 2018, 36, 603-612. [CrossRef] [PubMed]

49. Muegge, B.D.; Kuczynski, J.; Knights, D.; Clemente, J.C.; Gonzalez, A.; Fontana, L.; Henrissat, B.; Knight, R.; Gordon, J.I. Diet drives convergence in gut microbiome functions across mammalian phylogeny and within humans. Science 2011, 332, 970-974. [CrossRef]

50. Frankowski, J.; Lorito, M.; Scala, F.; Schmid, R.; Berg, G.; Bahl, H. Purification and properties of two chitinolytic enzymes of Serratia plymuthica HRO-C48. Arch. Microbiol. 2001, 176, 421-426. [CrossRef]

51. Yuli, P.E.; Suhartono, M.T.; Rukayadi, Y.; Hwang, J.K.; Pyun, Y.R. Characteristics of thermostable chitinase enzymes from the indonesian Bacillus sp 13.26. Enzyme Microb. Technol. 2004, 35, 147-153. [CrossRef]

52. Tsuji, H.; Nishimura, S.; Inui, T.; Kado, Y.; Ishikawa, K.; Nakamura, T.; Uegaki, K. Kinetic and crystallographic analyses of the catalytic domain of chitinase from Pyrococcus furiosus-The role of conserved residues in the active site. FEBS J. 2010, 277, 2683-2695. [CrossRef]

53. Laribi-Habchi, H.; Dziril, M.; Badis, A.; Mouhoub, S.; Mameri, N. Purification and characterization of a highly thermostable chitinase from the stomach of the red scorpionfish Scorpaena scrofa with bioinsecticidal activity toward cowpea weevil Callosobruchus maculatus (Coleoptera: Bruchidae). Biosci. Biotech. Biochem. 2012, 76, 1733-1740. [CrossRef] 
54. Park, J.K.; Morita, K.; Fukumoto, I.; Yamasaki, Y.; Nakagawa, T.; Kawamukai, M.; Matsuda, H. Purification and characterization of the chitinase (ChiA) from Enterobacter sp. G-1. Biosci. Biotech. Biochem. 1997, 61, 684-689. [CrossRef]

55. Vaidya, R.; Roy, S.; Macmil, S.; Gandhi, S.; Vyas, P.; Chhatpar, H.S. Purification and characterization of chitinase from Alcaligenes xylosoxydans. Biotechnol. Lett. 2003, 25, 715-717. [CrossRef] [PubMed]

56. Bhushan, B.; Hoondal, G.S. Isolation, purification and properties of a thermostable chitinase from an alkalophilic Bacillus sp. BG-11. Biotechnol. Lett. 1998, 20, 157-159. [CrossRef]

57. Simunek, J.; Tishchenko, G.; Koppova, I. Chitinolytic activities of Clostridium sp JM2 isolated from stool of human administered per orally by chitosan. Folia Microbiol. 2008, 53, 249-254. [CrossRef]

58. Davies, D.A.L.; Pope, A.M.S. Mycolase, a new kind of systemic anti-mycotic. Nature 1978, 273, 235-236. [CrossRef]

59. Cabral, V.; Znaidi, S.; Walker, L.A.; Martin-Yken, H.; Dague, E.; Legrand, M.; Lee, K.; Chauvel, M.; Firon, A.; Rossignol, T.; et al. Targeted changes of the cell wall proteome influence Candida albicans ability to form single- and multi-strain biofilms. PLoS Pathog. 2014, 10, e1004542. [CrossRef]

60. Jimenezbarbero, J.; Prieto, A.; Gomezmiranda, B.; Leal, J.A.; Bernabe, M. Chemical-structure of fungal cell-wall polysaccharides isolated from Microsporum gypseum and related species of Microsporum and Trychophyton. Carbohydr. Res. 1995, 272, 121-128. [CrossRef]

61. Takeda, T.; Kawarasaki, I.; Ogihara, Y. Studies on the structure of a polysaccharide from Epidermophyton floccosum and approach to a synthesis of the basic trisaccharide repeating units. Carbohydr. Res. 1981, 89, 301-308. [CrossRef] 